ISSN 2078-6441. Вісник Львівського університету. Серія географічна. 2013. Випуск 42. С. 53-63. Visnyk of the Lviv University. Series Geography. 2013. Issue 42. P. 53-63.

911.3

\author{
т лія нич \\ ьвівський н ціон льний університет імені в н \\ вул. . орошенк, 41, 79000, м. ввів, кр їн
}

ро н лізов но історичні передумови розвитку з кл дів розміщення у регіоні. изн чено головні історичні ет пи розвитку готельної сфери. иокремлено основні чинники, що зумовили формув ння т розвиток з кл дів сфери гостинності. х р ктеризов но розвиток послуг, якість обслуговув ння, особливості рхітектурно-пл нув льної орг ніз ції готельних споруд. ведено історичні довідки про перші готелі у ьвові. ро н лізов но розвиток з кл дів розмішення у різні періоди. исвітлено вплив історичних передумов н розвиток готельної інфр структури. од но пропозиції щодо под льшої розбудови готельної інфр структури міст .

лючові слов : готельне господ рство, з кл ди розміщення, послуги гостинності.

юди, подорожуючи з різною метою т н мір ми, з вжди відчув ли потребу в притулку, х рчув нні т відпочинку. ому історія розвитку сфери гостинності нерозривно пов'яз н 3 подорож ми. отелі виник ли як з їжджі двори вздовж в жливих тр нспортних шляхів. отельне господ рство є головним чинником розвитку і основною скл довою туристичної інфр структури.

сторію туризму, зокрем сфери гостинності досліджув ли . пов л, . едорченко, . ьоров , . стименко, . льськ, . ндяк, . ньків т ін. 'ясув ння історичних особливостей ст новлення готельного господ рств в меж х ьвівської обл. т зокрем ьвов диференційов но з історичними ет п ми розвитку потребує більшої дет ліз ції.

ш мет - виявлення головних ет пів т особливостей розвитку сфери гостинності н з с д х принципу історизму. еручи до ув ги з г льні риси, переломні віхи у господ рському т суспільному житті кр їн вропи, до скл ду яких у різні ч си входил територія ьвівської обл., с ме: встро- горськ імперія (1772-1918),

ольськ республік (1919-1939), (1941-1991) т кр їн (з 1991 р.), ми виокремили т кі періоди розвитку з кл дів готельного типу у ьвові т обл сті:

- період иївської усі (послуги гостинності н д в ли гостинні двори, корчми);

- $\quad$ - V ст. (нем конкретної інформ ції щодо н явності з кл дів розміщення);

- встрійський період (один 3 н йбільш успішних періодів у соці льноекономічному, культурному, н уковому розвитку міст ; розбудов цілої мережі готелів, широк пропозиція готельних послуг);

- польський період (період обмеженої появи нових з кл дів розміщення);

- p дянський період (повоєнн відбудов мережі готелів, змін їхніх н зв, л тентн диференці ція готелів з соці льним, отже, м йновим ст тусом користув чів);

- період нез лежної кр їни (1991-2000 рр. - ст гн ція готельного господ рств обл сті н тлі з г льного економічного з неп ду; з 2000 р. - стрімк відбудов мережі з кл дів розміщення у ьвові т обл стіз г лом).

(C) нич ., 2013 
ожен із з зн чених періодів розвитку готельної сфери м є особливості орг ніз ції, функціон льні з вд ння, н прями т форми сервісної діяльності.

ерші з кл ди готельного типу н території кр їни виник ли у - ст., у період економічного т політичного розвитку иївської усі. игідне геогр фічне положення иївської усі н перехресті торгових шляхів, культурні т релігійні зв'язки з кр їн ми ередземномор'я, лтики, хідної вропи зумовили розбудову міст т появу спеці лізов них з кл дів розміщення. еред перших з кл дів гостинності у иївській усі були постоялі двори, розт шов ні один від одного н відст ні кінного переходу, які н зив ли "ями" (поштові ст нції). розвитком поштового сполучення у V ст. постоялі двори створюв ли біля поштових ст нцій, підпорядков них мському н к зу. великих міст х виник ли гостинні двори, що м ли вищий комфорт порівняно з постоялими двор ми. хніми послуг ми користув лись головно купці, держ вні службовці, т м були створені умови для проведення комерційних опер цій у структурі виділялись кр мниці, торгові ряди, скл дські приміщення. остинні двори не були численними, проте виділялися зн чними розмір ми, ізольов ністю т с мобутністю, особливо щодо розселення іноземців з н ціон льною озн кою. зовні гостинні двори ч сто обгороджув ли оборонними стін ми, б шт ми, вони м ли декільк в’їзних воріт.

чум цьких і торгових шлях х кр їни послуги гостинності н д в ли корчми, що торгув ли хмільними н поями, були місцем зупинки для подорожніх, місцем розв г. орчми в окремих регіон х н зив ли т кож “шинком”, “корчмою-з їздом”, вони м ють д вню історію, відомі ще з ч сів иївської усі [5, с. 41-42].

ьвів т його околиці прив блюв ли людей зд вн , зокрем через зручність розт шув ння н перехресті великих і в жливих торговельних шляхів між вропою т зією. е 3 ст. до ьвов приїждж ло 6 г то купців, оскільки він був осередком н великому торговому шляху від орного моря ж до д нськ . ьвові з вжди шук ли притулок купці з вропи, які рух лися н хід і ч сто з лиш лися в місті н довше, приїждж ли до ьвов т кож держ вні діячі. вл сне т ке вигідне розт шув ння міст д ло поштовх для розвитку з кл дів готельного типу. ж ль, до н ших днів інформ ції про перші готелі н личині не збереглося.

одноч с змінюв лося функціон льне призн чення міст . торговельного центру ьвів перетворився в промислове місто з ч сів р дянської вл ди, сьогодні - в жливий культурний т туристичний центр кр їни.

ормув ння ринку готельних послуг регіону прип ло н $\mathrm{V}-$ ст. і тісно пов'яз не з процес ми концентр ції у міст х промислового виробництв, торгових i підприємницьких структур, пожв вленням економічної співпр ці й розбудовою мережі з лізничного сполучення. 1895 р. зі ьвов вирушив перший туристичний поїзд 3 м ршрутом ьвів- коле. ьвів ст в одним із н йбільших 3 лізничних вузлів встрогорщини. озвиток інфр структури зручного й порівняно недорогого 3 лізничного тр нспорту породив явище м сового м ндрівництв, відт к сприяв розбудові мережі недорогих муніцип льних готелів для м ндрівників і підприємців. л сне тоді в кожному містечку личини поч ли з'являтися великі і м ленькі готелі. звич й перші готелі м ли досить скромний інтер'єр, проте н віть у н йскромнішому з кл ді розміщення були кімн ти поліпшеної якості, призн чені для з можних відвідув чів. 1902 p. у личині ( хідній т хідній) н лічув лося 935 готелів, 3 них у ьвові - 48. ля порівняння, у р кові було 18 готелів, рш ві - 32. ри т ких готелях діяли к в'ярні т рестор ни [1, с. 152]. 
ільшість готелів м л низький рівень комфорту - скромне оформлення інтер'єру, без водопроводу, к н ліз ції. я к тегорія готелів бул розр хов н н клієнтів із низьким м тері льним дост тком, комерційних гентів. цьому фоні контр стув ли великі т поодинокі м лі готелі з дорогим оздобленням інтер'єру, розкішними меблями, вишколеною обслугою, комун льними зручностями. кі готелі відповід ли тогоч сному стилю фешенебельних європейських готелів. великих дорогих готелях, з звич й, були рестор ни, к в'ярні, л зні, тому прожив ння могли собі дозволити лише особливо з можні клієнти.

ерші готелі н ьвівщині з'явилися у ьвові. ершим львівським готелем після готелю в к сині ехт був готель н вул. роля юдвік , 15, н місці теперішнього узею етногр фії т художнього промислу н проспекті вободи, його н зив ли “ ід имським ез рем". риповерхову будівлю спорудив підприємець ог нн решель у 1785 p. ля будівництв використ ли цеглу розібр ного шпит лю вятого ух н теперішній площі в н ідкови. поч тку ст. будинок готелю вв ж ли н йбільш імпоз нтною к м'яницею н ижніх л х після уберні льного упр вління. 1800-1839 рр. к м'яницю з йм л енер льн військов коменд тур .

ісля перебудови, яку провів ільельм мідт, 1 листоп д 1840 р. тут знову відкрито готель “ ннглійський” (рис. 1). ідкрив його підприємець елікс янг з рн . риповерховий готель н лічув в 100 мебльов них номерів. 1870 р. бул спроб розробити проект нового готелю “ нглійський”, відбувся н віть конкурс. дн к 1888 р. будівлю готелю розібр ли і з кл д перемістили н вул. роля юдвік , 25 (сьогодні проспект вободи), де був готель “ ід ілим конем”. тому місці збудув ли споруду лицької ощ дної к си (тепер це узей етногр фії т художнього промислу).

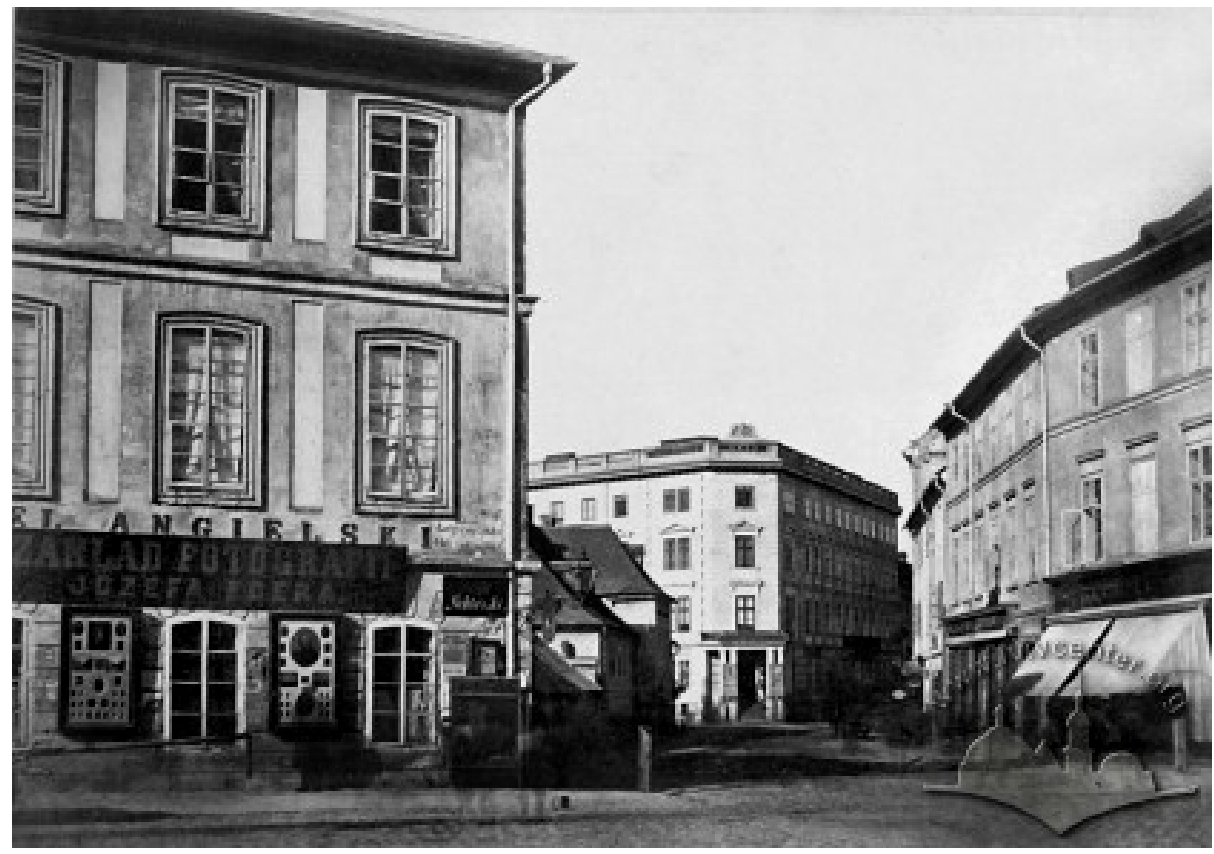

ис. 1. отель “" нглійський”, 1840 [10]. 
прикінці $\mathrm{V} \quad-\mathrm{H}$ поч тку ст. у ьвові відбулося ст новлення готельного господ рств як с мостійної г лузі. структурі готелів пр цюв ли рестор ни, к в'ярні, клуби з інтерес ми. кл ди гостинності н були поширення, підвищився комфорт, готелі н були озн к ідентичності. ості м ли змогу вибир ти готель відповідно до свого соці льного ст ну [8, с. 256].

н менитими готельними з кл д ми ьвівщини того ч су вв ж ли т кож готелі “ орж”, “ р нд”, “ рістоль”,“ етрополь”, “ р ківський”, “ вропейський” т б г то інших.

ерш будівля готелю “ орж” зведен 1793 р. отель, споруджений з проектом невідомого рхітектор у стилі тогоч сних з їджих дворів, м в н зву “ ід трьом г к ми”. убліцист і дослідник ьвов т нісл в нюр- епловський х р ктеризув в його як дешевий з їзд, що з вдяки цьому м в велику популярність. 1811 р. вл сник

орж офм н збудув в новий готель “De Russie”, що м в дві в’їзні бр ми з боку площі т чудовий с д. 1875 p. рхітектор дмунд елер спорудив у с ду те тр льний з л для німецького тов риств “" розінн”, до 1894 р. тут відбув лися вист ви, к рн в ли, з сід ння. отель перейменов но 3 іменем одного із з сновників орж офм н . квітні 1899 р. будинок готелю знесено. годом, 8 січня 1901 р. відбулося урочисте відкриття нового готелю “ орж”, збудов ного рхітектурно-будівельною спілкою в н евинського т зеф ибульського 3 проектом віденських рхітекторів ерм н ельмер т ердин нд ельнер . мієборець" скульптор нтоні опеля т легоричні скульптури, які символізують зію, фрику, вропу й мерику вторств еон рдо рконі (рис. 2). отель м в 93 номери, 32 з яких - п рт менти. новому розкішному готелі було центр льне оп лення, електричний ліфт, телефони, г ряч $\mathrm{T}$ холодн вод . вич йний номер коштув в 6-12 зл. 3 добу, “люкс" - 13-24 зл. еликою популярністю користув лися першокл сний рестор н і к в’ярня.

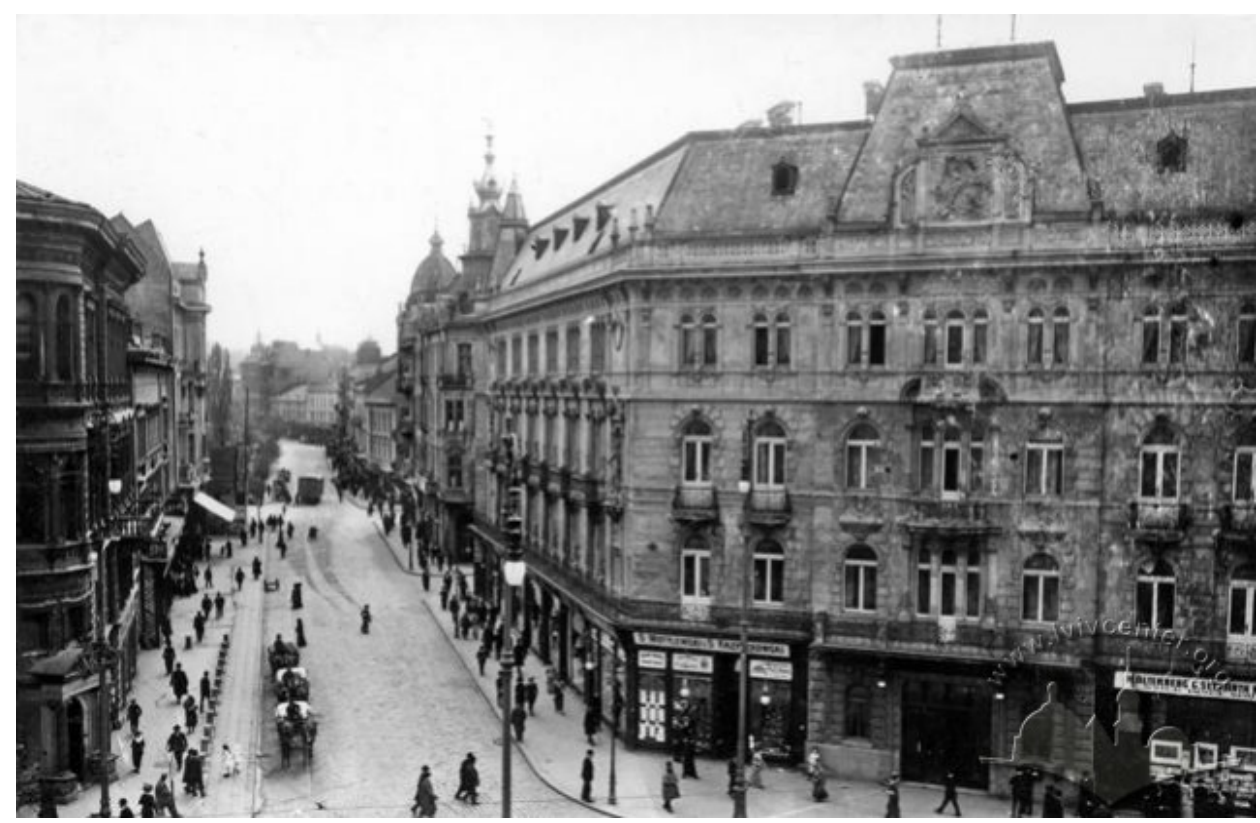

ис. 2. отель “ орж”, 1905 [10]. 
р дянських ч сів готель н зв ли “нтурист”, його рестор н 3 кільком з л ми був тоді н йпрестижнішим у місті. боку проспекту евченк бул популярн у 1960-х рок х к в’ярня. 1995 р. готелю повернули н зву “ орж”. 2010 р. перший поверх готелю зд ють в оренду вл сник м кр мниць [7, с. 165].

отель “ вропейський” (“Hotel d'Europe”) був одним з н йст ріших готелів, відкритий 1804 р. н пл. рійській, 4 (у 1843-1871 pp. - площ ердин нд , 31944 р. пл. іцкевич ) (рис. 3). 1826 р. збудов но двоповерховий готель, який перебудув ли в неоренес нсному стилі 1870 p.

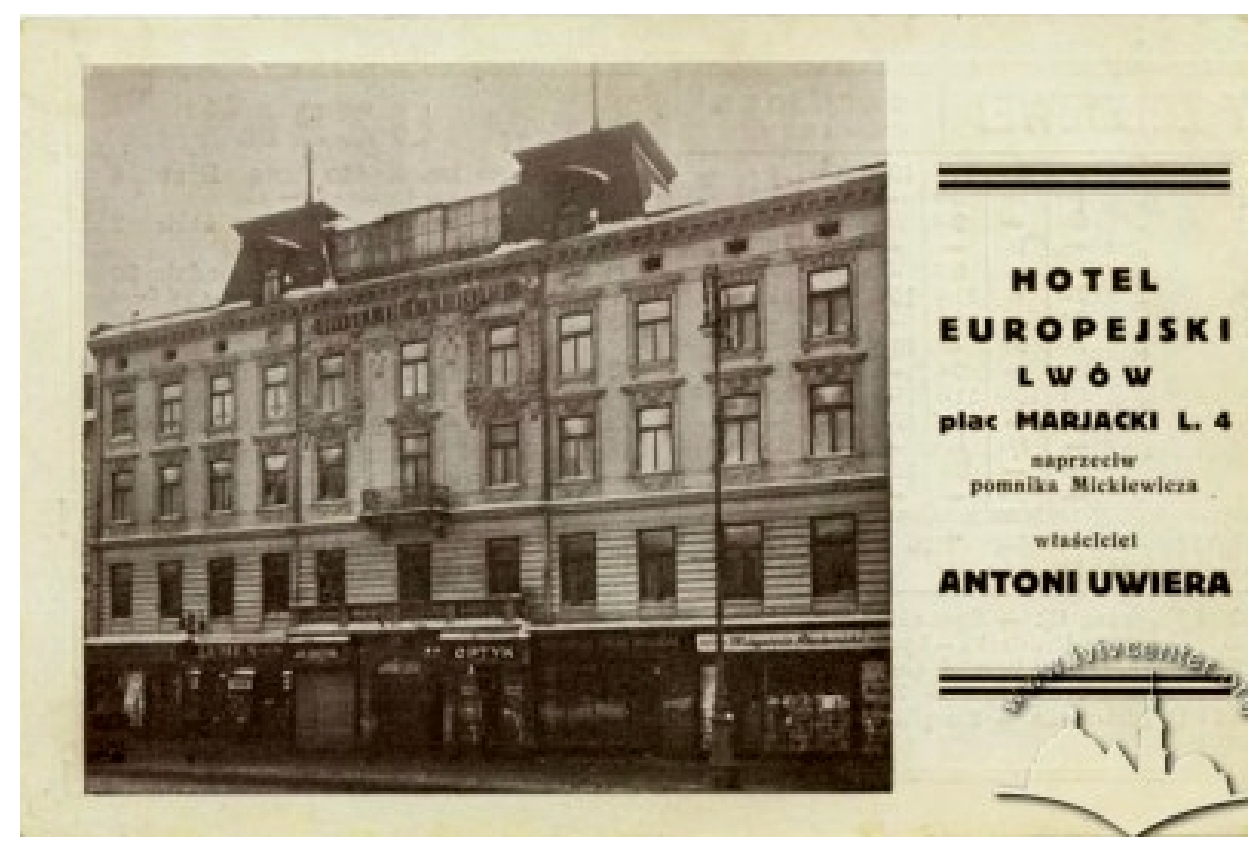

ис. 3. отель “ вропейський”, 1920-1939 [10].

1934-1936 pp. рхітектор ердин рд сслєр н пл. рійській, 4 збудув в новий готель у стилі функціон лізму н 65 номерів, 1939 р. в прибудові н подвір'ї відкрито к в'ярню “ тук”. р дянських ч сів готель н зив вся “ кр їн ” (див. рис. 4). отельний будинок було знесено у 2004 р., через дв роки тут відбудов но новий $з$ пл н ми кінця ст., де розт шув л сь фін нсов уст нов “ крексімб нку”.

1804 р. н пл. рійській, 5 з снов ний готель янг . ісля ч сткової перебудови новий вл сник ільгельм ебер н зв в готель “р нцузьким”. готелі містил ся т кож цукерня зимир очк . 1920-х рок х з проектом . сслєр прибудув ли з склений торговельний п с ж “ рійськ г лерея”. р дянських ч сів тут був “ итячий світ”, потім квітков “оксол н”, сьогодні тут м г зин мережі дитячих тов рів “ нтошк” $[7$, с. 166].

вколо пл. ерн рдинської (тепер площ оборн ) у к м'яницях було кільк готелів. чотириповерховому будинку 5, збудов ному у 1860-х, до 1970-х років розміщув вся готель “ рш вський”, перебудов ний потім під гуртожиток для військових. будинку 7 - з їзд “ ід ленем”, “ ов льський”, з 1913 р. - “ р ківський”. 


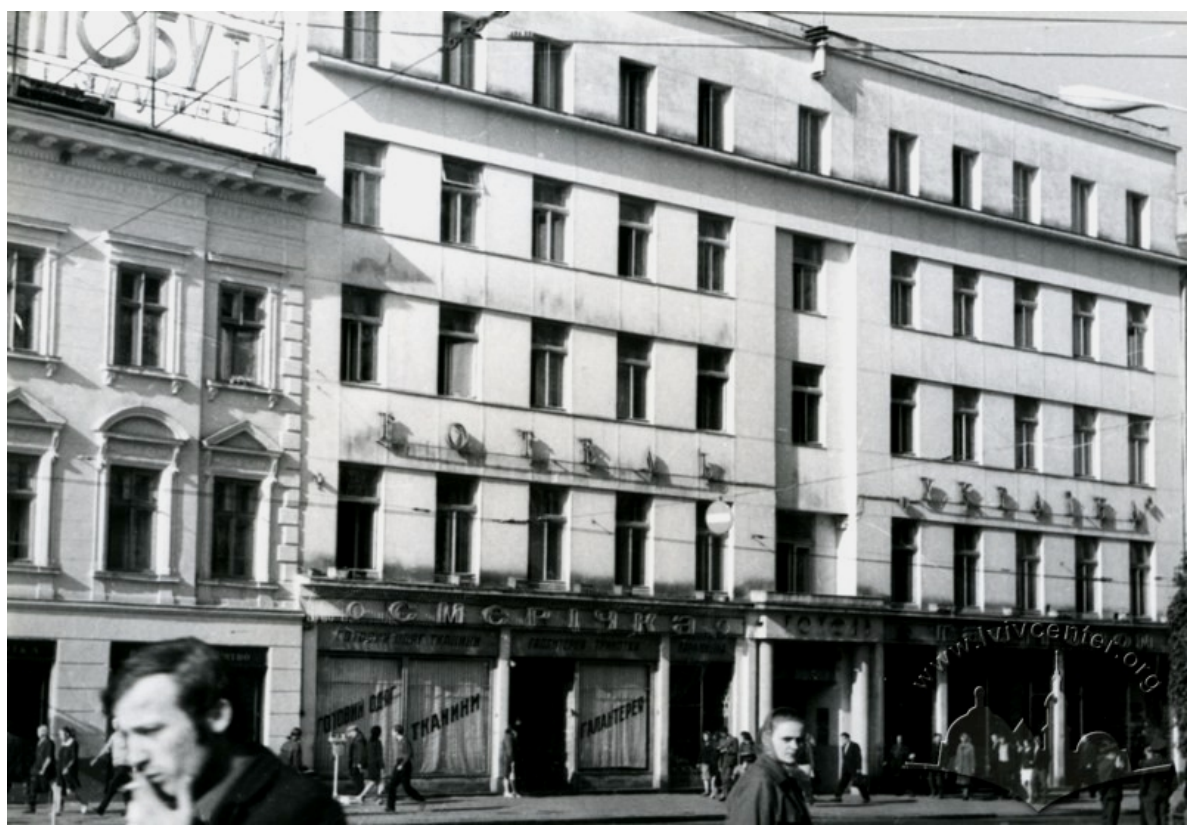

ис. 4. отель “ кр їн ”, 1965-1970 [10].

поч тку вул. ек рської були дв готелі. іворуч - “р ківський”, пр воруч “ етрополь”, н розі вул. ек рської т пл. оборної. ут пр цюв л т кож к в’ярня. ісля війни обидв готелі втр тили свої функції.

отель “ р ківський” споруджено у 1913-1914 pр. $з$ проектом дмунд ихович т іх л ужецького н місці ст рої будівлі з 1881 р. н вул. ек рській, 1 . е був н йбільший т н йкомфорт бельніший тогоч сний львівський готель. р дянських ч сів у будинку розт шув ли будівельний технікум, тепер - коледж будівництв , рхітектури т диз йну. с дн ч стин готелю виходить н пл. оборну, 7. епер тут пеляційний суд ьвівської обл сті т ьвівський н уково-дослідний інститут судових експертиз.

отель “ ід тигрисом” був н місці колишнього кіноте тру “ кр їн ”, у ньому оселялися н йбідніші гості, оскільки був дешевим. ри готелі пр цюв в рестор н, де зустріч лися львівські літер тори. годом готель зруйнув ли і збудув ли у 1872 p. лицький іпотечний б нк, ч стину першого поверху з 1937 р. 3 йм в кіноте тр “ вроп”, згодом кіноте тр “кр їн”. іноте тр “кр їн”н пл. лицькій, 15 т розі к демічної (тепер проспекту евченк ) до поч тку 1960-х років був н йбільшим т н йпрестижнішим львівським кіноте тром.

отель “ ью- орк” споруджено н вул. роля юдвік , 45 у 1875 р. 3 проектом м нуїл лля. 1910-1912 рр. його перебудув л фірм іх л лям в стилі модернового кл сицизму. р дянських ч сів з 1945 р. тут був готель “ ніпро”, який ув ж ли “обкомівським”. отириповерхову п м'ятку рхітектури місцевого зн чення розібр ли, щоб збудув ти н поч тку ст. “П’ятиповерховий” готель “ пер ”. спр вді споруд м є 7 поверхів і вдвічі перевищує сусідні к м’яниці.

отель “ ентр льний” відкрили 1891 р. у домі, спорудженому в 1882-1884 pр. 3 проектом м нуеля лля н вул. роля юдвік , 11. 1910 р. готель реконструйов - 
но будівельною фірмою дмунд ихович в нглійському модерному стилі. другому поверсі відкрито к в’ярню “ іті” з довгим б лконом уздовж ф с ду. осі зберегл ся б лконн б люстр д з листяним рисунком. р дянських ч сів н першому поверсі пр цюв ло популярне к фе “ ьвів'янк”. ісля ост нньої реконструкції к м’яниці у 1990-1992 рр. вон ст л ч стиною готельно-рестор нного комплексу “р нд-готель" [7, с. 249].

отель “р нд” відкритий 1893 р. н вул. роля юдвік, 13. отель м в 48 номерів, рестор н, вирізнявся оригін льною рхітектурою, інтер'єр викон но в необ роковому стилі 3 проектом р зм рм тник. е був один 3 н йрозкішніших готелів у місті. 1893-1895 рр. його вл сник фр їм усм нн збудув в з готелем відкритий п с ж. епер колишній п с ж усм нн н зив ється проїздом рив ип . р дянських ч сів готель м в н зву “ ьвів”, з з 1964 р. - “ ерховин ”. 1990-1992 рр. готель реконструюв ли 3 м ксим льним відтворенням його ст ну кінця ст. окрем , відрест вров не ліпне оздоблення ф с дів, відтворено декор тивне оформлення інтер'єрів, з стосов но стильні елементи декору.

удинки 19 і 21 н вул. роля юдвік, споруджені в середині ст., 3 вжди слугув ли як готелі. 80-х років ст. тут був готель “ ід орним орлом”, 3 кінця ст. до 1939 р. - готель “ рістоль” игмунт енгут . игідне розт шув ння н одній з центр льних вулиць, помірков н в ртість номерів г р нтув ли вл снику успіх.

п ртері 1907 р. відкрився один з перших кіноте трів “The Empire Vio”. . енгут 3 пров див в будинку 21 кошерний рестор н, 31930 р. у розкішній з лі відкрили т нцюв льний 6 р "Palais de Danse - Bristol" з нічними розв ж льними прогр м ми. ід ч с німецької окуп ції тут т кож був готель т рестор н 3 пивним б ром. ісля війни ще кільк років офіційною н звою з лиш вся “ рістоль”. пізніші ч си, зі зміною н зви вулиці н вул. 1 р вня, готель 3 рестор ном т кож перейменув ли н “ ершотр вневий” (рис. 5). приміщеннях першого поверху розт шув ли годинникову м йстерню т перук рню. суч сному ет пі в колишньому готелі з рестор ном розт шов ні торгові приміщення.

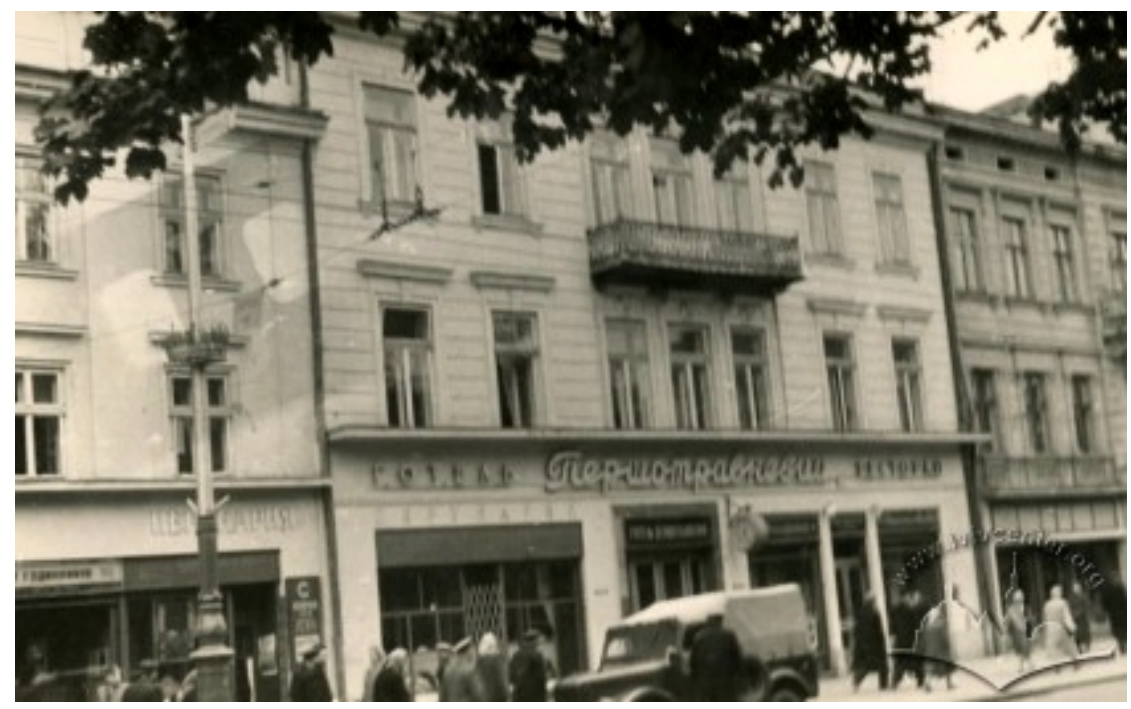

ис. 5. отель “ ершотр вневий”, 1950-1960 [10]. 
отель “ ель- ю” (“Belle Vue”) був у будинку 27 н вул. роля юдвік . удинок спорудили 1896 р. в неоренес нсному стилі з проектом игмунд ендзерського. отель м в концертну з лу. олишня н зв готелю - “ літ”. 1954 р. тут був удинок моделей одягу. епер тут розт шов ні торгові приміщення.

отель “ родн гостинниця” збудов но у 1904-1906 pp. н розі вулиць орошенK, 20 т остюшк, 1 з проектом дея бмінського. ри готелі були к в'ярня т рестор н. р дянських ч сів тут діяв готель т рестор н “ родний”, 31999 р. в будинку розмістил ся хідн регіон льн митниця.

отель “ сторія” збудов но 3 проектом рхітектор . ртеля 1912-1914 рр. у стилі пізнього модерну. годом готель перейменув ли н “ иїв”, у 1990-х рок х він 3 неп в і втр тив будь-яку прив бливість, 9 липня 2010 р. готелю повернуто н зву “ сторія” т розпоч то реконструкцію.

отель “ід трьом мурин ми ( фрик нцями)” з снов ний 1920 р. н вул. р ківській, 9. ут був т кож рестор н. першому поверсі відтворено фр гменти розписів стін т стель з ст., які тепер прикр ш ють інтер'єр к в’ярні “ реск ”.

н чного поширення в личині н були п нсіон ти - мебльов ні кімн ти, створені н зр зок з хідноєвропейських і розр хов ні н трив ле перебув ння гостей. нсіон ти були меншими з розмір ми, ніж готелі, м ли сімейний з тишок. ут н д в ли окремо кімн ти для сну, їд льня і с лон були спільними.

ід ч с ругої світової війни господ рство хідної кр їни суттєво постр жд ло. роте вже після війни простежено пожв влення туризму. озвиток туризму зумовив розширення туристичної інфр структури - будівництво нових готелів, мотелів, кемпінгів.

отель “ ьвів” збудов но 1965 р. (рис. 6). той період готель був візитівкою ьвов й осередком туризму н хідній кр їні. отель користув вся дуже великою популярністю серед гостей міст , т кож серед туристів із ередньої зії т ходу.

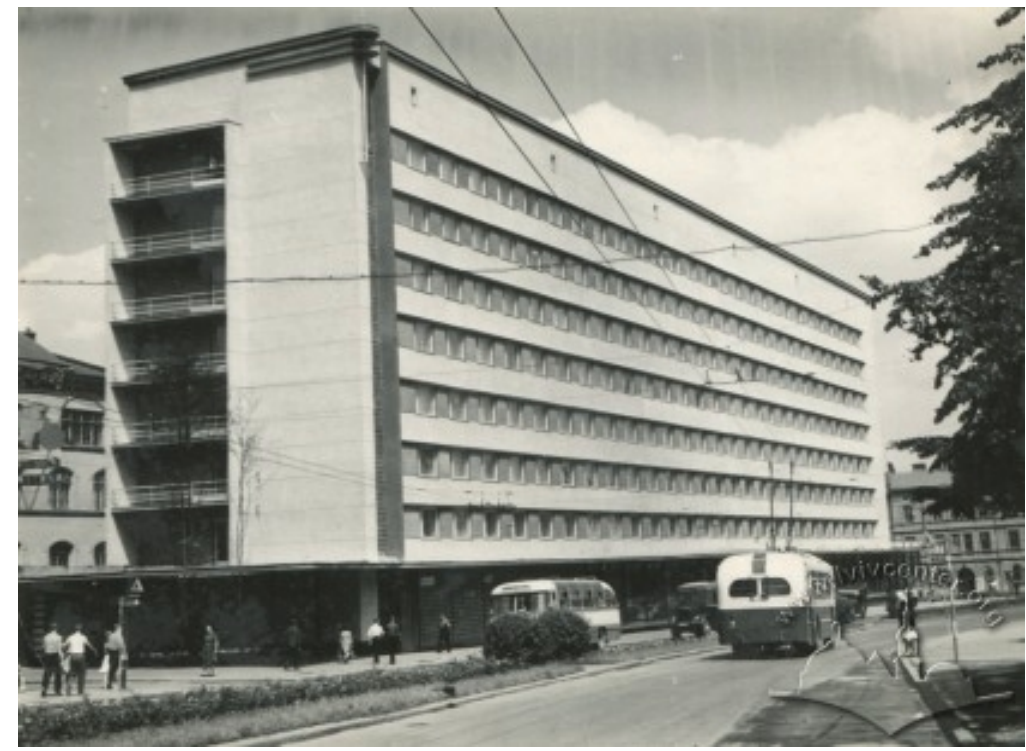

ис. 6. отель “ ьвів”, 1965-1970 [10]. 
1973 р. н вул. ерш ківців, 6 відкрито готель “ льянівський”. ля того ч су відкриття готелю т кого рівня було визн чною подією. 1991 р. p зом зі здобуттям для кр їни нез лежності готель перейменув ли н “ ез лежність”. ісля реконструкції суч сн н зв готелю “ вроготель” пов'яз н з пр гненням впров джув ти у ьвові укр їнські тр диції європейської гостинності.

отель “ л ст ” споруджено 1976 р. н вул. леп рівськ , 30, перед ст діоном

поч тку 1990-х готель перейменов но (колишня н зв “ осія”). отель в будівлі 3 йм є 12 поверхів і м є 157 номерів н 289 місць. готелі $є$ дв 6 ри, рестор н н 170 місць, перук рня, пр льня, конференц-з л н 80 місць, пл тн втостоянк .

отель “ ністер” збудов но у 1983 р. н м льовничому п горбі біля ст ровинного п рку. р дянські ч си готель був фл гм ном готельної індустрії міст і н леж в до системи “ нтурист”. вересні 1999 р. “ ністер” отрим в к тегорію “4 зірки”.

отель “ етьм н” споруджено 1984 р. н вул. олодимир еликого, 50. е суч сний готельний комплекс, який м є досвід у проведенні міжн родних конференцій, бізнес-семін рів, конгресів. ст ння реконструкція готелю проведен 2001 р.

отель “ упутник” збудов но 1989 р. е з тишний конференц-готель, розт шов ний непод лік центр льної ч стини міст . облизу готелю є великі торгові центри, розв ж льні з кл ди т кв п рк міст .

тже, з кл ди готельного типу ьвівської обл. м ють д вні тр диції. піцентром розвитку готельного бізнесу регіону було й $є$ місто ьвів.

3 н явних в обл сті у 2012 р. 171 готелів 67 (39\%) розт шов но с ме у ьвові [9].

орівняно з 2000 р. кількість готелів у місті зросл у 2,5 р з. о готелів з високим рівнем комфортності н леж ть “р нд-готель” 4-*, “ пер ” 4-*, “ ністер” 4-*, “ еополіс" 4-*, “ вейц рський” 4-*, “ упутник” 4-*, “ мок ев ” 3-*, “ ней” 3-*, “ тон”3-*, “ вроготель” 3-*, “ олтер” 3-*, “ орж” 3-*. роте ост ннім ч сом простежено деяке зменшення концентр ції з кл дів розміщення у ьвові. томість суттєво зросл ч стк колівського дміністр тивного р йону, що зумовлено ктивним розвитком туризму [3].

н ліз розвитку з кл дів розміщення у різні періоди д є змогу оцінити вплив історичних умов н розвиток мережі 3 кл дів розміщення т готельної інфр структури. о переліку чинників, які зумовлюють періодиз цію розвитку готельної сфери ьвов й обл сті н леж ть:

- розт шув ння н перехресті в жливих торговельних шляхів в усі періоди, у тому числі й нині;

- розвиток з лізничного тр нспорту т м сового м ндрівництв в період встрійської імперії; висок якість обслуговув ння, що відповід л світовим ст нд рт м;

- пожв влення туризму т розширення мережі з кл дів розміщення в $\mathrm{p}$ дянський період;

- зн чне зрост ння туристичних потоків, як внутрішніх, т к і міжн родних, н суч сному ет пі;

- зрост ння туристичної прив бливості регіону т особливо його центру;

- проведення з ходів мег рівня, н прикл д, чемпіон т вропи з футболу 2012 р., вітовий конгрес укр їнців у 2013 р. тощо.

тже, ьвів є одним 3 н йвідоміших туристичних центрів кр їни, тепер і вропи. ор з більшого зн чення для економіки ьвов т обл сті н був є туризм. ьогодні м ємо чітку тенденцію зрост ння туристичних потоків до регіону. кількістю підприємств готельного господ рств регіон посід є третє місце в кр їні. дн к 
ще потрібно вирішити проблему з в нт женості готелів, відповідності певній к тегорії зірковості, особливо декв тності в ртості прожив ння рівню комфорту і сервісу, особливо н тлі ктивного зрост ння обсягів пропозицій н ринку короткотермінової оренди житлових площ.

1. инничук . н йпи ьвов / . инничук. - ьвів : “ ір мід ”, 2001. - 290 с.

2. нич . . отельне господ рство ьвівської обл сті: суч сний ст н т шляхи оптиміз ції розвитку / . . н нич // існик ьвів. ун-ту. ер. міжн р. відносини. 2012. - ип. 29, . 1. - . 24-29.

3. нич . . еогр фія з кл дів готельного типу у ьвівській обл сті / . . нич, . . бінськ // еогр фічн н ук і пр ктик : виклики епохи: тері ли міжн р. н ук. конф., присвяченої 130-річчю геогр фії у ьвівському університеті. - ьвів : ид вничий центр імені в н р нк , 2013. - . 3. - .261-266.

4. отельне господ рство т туризм у ьвівській обл сті : т тистичний збірник. ьвів, 2011. - $111 \mathrm{c}$.

5. льськ . . отельний бізнес: теорія т пр ктик : [н вч. посібник] / . . льськ , . . ндяк. - . : ентр учбової літер тури, 2009. - 472 с.

6. льськ . . рг ніз ція готельного обслуговув ння : [підручник] / . . ндяк, . . НьКо. - . : н нНЯ, 2011. - 366 с

7. ельник . . ьвівські вулиці і к м'яниці, мури, з к м рки, передмістя т інші особливості оролівського столичного міст личини / . . ельник. - ьвів : ентр вропи, 2008. - 384 с.

8. тецюк . . отельне господ рство ьвов : суч сні тенденції розвитку / . . тецюк // існик ьвів. ун-ту. ер. геогр. - 2012. - ип. 40, . 2. - . 163-169.

9. фіційний с йт ьвівської міської р ди [ лектронний ресурс]. - Режим доступу: http://city-adm.lviv.ua.

10. рб ністичні обр зи : [ лектронний ресурс]. - Режим доступу: http://www.lvivcenter.org/uk.

11. стименко . . сторія туризму : [н вч. посібник] / . . стименко, . Ф н сьєв. - ., 2005. -320 с.

12. едорченко . . сторія туризму в кр їні : [н вч. посібник] / . . едорченко, . . ьоров . - ., 2002. - 195 с. 


\title{
HISTORIC AND GEOGRAPHIC PECULIARITIES OF THE HOTEL SPHERE DEVELOPMENT IN LVIV
}

\author{
Nataliya Hanych \\ Ivan Franko National University of Lviv, \\ P. Doroshenko Str., 41, UA - 79000 Lviv, Ukraine
}

The historic preconditions of the lodging sites development are analyzed. The historic periods in the hotel sphere development are described. The main factors that lead to the formation and development of the hotel establishments are singled out. The development of services, quality of service, features of hotels architectural planning is characterized. The historic references on the first hotels in Lviv are submitted. The development of accommodation facilities in different time periods is traced. The influence of the historical background on the development of hotel infrastructure is analyzed. The recommendations on the future development of hotel infrastructure in Lviv are worked out.

Key words: lodging, accommodation, lodging services.

\section{т лия нич}

ьвовский н цион льный университет имени в н ул. . орошенко, 41, 79000, ьвов, кр ин

ро н лизиров но исторические особенности $\mathrm{p}$ звития з ведений $\mathrm{p}$ змещения в регионе. пределено гл вные исторические эт пы р звития гостиничной сферы. ыделено основные ф кторы, обусловившие формиров ние и р звитие з ведений сферы гостеприимств . х $\mathrm{p}$ ктеризов но р звитие услуг, к чество обслужив ния, особенности рхитектурно-пл нировочной орг низ ции гостиничных сооружений. риведено исторические спр вки о первых гостиниц $\mathrm{x}$ в городе. ро н лизиров но р звитие средств р змещения в $\mathrm{p}$ зные временные периоды. свещено влияние исторических ф кторов н р звитие гостиничной инфр структуры. ссмотрено предложения по д льнейшему р звитию гостиничной инфр структуры ьвов .

лючевые слов : гостиничное хозяйство, з ведения р змещения, услуги гостеприимств . 